\title{
Cell Therapy and Critical Limb Ischemia: Evidence and Window of Opportunity in Obesity
}

\author{
Sally L. Elshaer, Renee E. Lorys and A.B. El-Remessy*
}

Clinical and Experimental Therapeutics, College of Pharmacy, University of Georgia, Augusta, Georgia 30912, USA

Received: : August 11, 2016; Accepted: September 12, 2016; Published: September 15, 2016

*Corresponding author: A.B. El-Remessy, Clinical and Experimental Therapeutics, College of Pharmacy, University of Georgia, Augusta, Georgia 30912, USA, Tel: +1-706.721.6760; Fax:+1-706.721.3994; E-mail: aelremessy@augusta.edu; aelremessy@outlook.com

Keywords: Critical limb ischemia; Inflammation; Metabolic syndrome; Stem cell therapy

\section{Critical Limb Ischemia}

Critical Limb Ischemia (CLI) is the most advanced clinical stage of advanced Peripheral Artery Disease (PAD). CLI occurs in approximately $12 \%$ of American adults [1]. CLI is a chronic disease process that occurs when an atherosclerotic blockage in the arteries markedly reduces blood flow and oxygenation to the extremities. It is defined as rest pain or impending limb loss secondary to proven arterial occlusion for more than two weeks [2]. This arterial insufficiency can manifest as ischemic rest pain, slow-healing ulcers, and gangrene. CLI is associated with high morbidity and mortality. If left untreated, CLI can lead to amputation of a limb and significant disability of an individual [3]. Indeed, $30 \%$ of patients with CLI undergo limb amputation, and the five-year mortality rate is $60 \%$ [1]. So far, there is no pharmacotherapeutic agent available for the treatment or prevention of CLI. The current treatment options aim at improving distal arterial perfusion by endovascular or surgical approaches or combination of both. However, amputation is often inevitable in the majority of patients [4].

\section{Mechanisms of Physiological Vascular Repair}

Ischemia is defined as a state in which blood flow is insufficient to meet metabolic demands. A functional response to increased metabolic demand is dilation of arteries along with decreased vascular resistance. Endothelium-dependent vasodilation can be impaired in presence of cardiovascular risk factors such as hyperlipidemia, diabetes mellitus, hypertension and tobacco use [5], which could be attributed in part to decreased production and increased degradation of nitric oxide [6]. Patients with PAD experience impaired vaso-reactivity [7], which renders intra-arterial infusions of vasodilators ineffective [8]. Functional response to ischemia is followed by structural alterations in the vasculature. These alterations include angiogenesis, arteriogenesis and vasculogenesis. Angiogenesis was first described by Judah Folkman in 1971 [9] and is defined as the expansion of microvasculature, because of sprouting of
Endothelial Cells (ECs) from pre-existing capillaries, followed by their proliferation, migration, and capillary formation [10]. By contrast, arteriogenesis describes the remodeling of existing collateral channels, so that they can deliver more blood flow to the limb [11]. Finally, adult vasculogenesis involves the recruitment of Endothelial Progenitor Cells (EPCs), which migrate from the bone marrow to the area of ischemia and differentiate to form new blood vessels [12].

On the other hand, muscle ischemia is associated with an increase in oxidative stress [13]. Oxidative stress occurs when the cell or tissue fails to detoxify the free radicals produced during metabolic activity. Free radicals damage proteins, lipids and nucleic acids. The excessive production of free radicals may be a unifying mechanism of vascular and skeletal muscle injury in PAD. Inflammatory process was also shown to play a key role in response to vascular injury, initiating recovery. Inflammatory mediators including cell adhesion molecules, cytokines, chemokines and growth factors direct the recruitment of inflammatory cells including monocytes/macrophages, neutrophils, and T-lymphocytes to the site of injury. Platelets are also important for the elaboration of inflammatory mediators [14]. Recruitment of EPCs can also be initiated through inflammation to induce repair [15]. While oxidative stress and inflammation are involved in the repair and initially activated as an adaptive mechanism, excessive oxidative stress or persistent release of inflammatory mediators can inhibit angiogenesis.

\section{Cell therapy in CLI: window of opportunity}

Under normal physiological conditions, arterial wall injury triggers an inflammatory response to induce repair. Nevertheless, the reparative processes seem to be diminished in both diabetes and metabolic syndromes. Currently, lifestyle modification and surgical procedures are the only intervention available to prevent ischemia. To fill this gap in therapy, researchers are continuing to investigate possible molecular targets that could lead to the development of pharmaceuticals to not only treat but also prevent critical limb ischemia. To date, over 50 clinical studies have been reported on the treatment of peripheral artery disease with progenitor stem cells [16] with the first pilot clinical study reported in 2002 [17]. The next section will review and evaluate 
the prevalence of CLI in metabolic disorders including diabetes and obesity and whether cell therapy can offer a window of opportunity to effectively treat CLI. We are shedding light into studies performed in the period from 2000 to present. The key words used in the search were Critical Limb Ischemia (CLI) alone or in conjunction with diabetes, obesity, metabolic syndrome, stem cells, Endothelial Progenitor Cells (EPCs), Mononuclear Cells (MNCs) or Mesenchymal Stem Cells (MSCs).

\section{Stem cells commonly used in CLI}

A stem cell is defined by its capacity for both self-renewal and directed differentiation. Two broad categories of stem cells have been recognized; the Embryonic Stem Cells (ESCs) and the socalled adult stem cells. ESCs are derived from the inner cell mass of the fetal blastula and they are pluripotent. They have the ability to differentiate into any cell type or any organ found in the adult body including; endodermal, mesodermal or ectodermal lineage [18]. On the other hand, adult stem cells exist in the bone-marrow and the circulation or as residents within a specific tissue [19]. In contrast to ESCs, adult stem cells are multipotent. They can give rise to cells of a given germ layer, in other words, they are lineage-committed [20].

The therapeutic application of adult stem cells in vascular regeneration is farther along in clinical development than any of the other stem cell approaches [21]. There are number of traits that make adult stem cells appealing in the field of cell-based vascular regeneration. Most of the time, they are isolated from the patient in whom they are ultimately to be injected and there is no need to overcome an immunologic barrier. Moreover, their use is not burdened by the ethical concerns that surround the use of human embryos [21]. In the following section, we will overview the common types of adult stem cells that have been shown to be of therapeutic potential in CLI.

\section{Bone Marrow Derived Mono-Nuclear Cells (BM- MNCs)}

BM-MNCs contains mixed population of cells that have not been completely characterized [22], yet includes hematopoietic cells, fibroblasts, osteoblasts, and myogenic cells as well as endothelial lineage [23]. Within this population of cells, there are true Endothelial Progenitor Cells (EPCs) that can incorporate into the vascular network. These cells constitute 1-2 per 100 million MNCs [24].

\section{Endothelial Progenitor Cells (EPCs)}

EPCs were first identified from the bloodstream and recognized for their regenerative potential in 1997 [25]. EPCs are a subgroup of peripheral blood monocytes that express stem celllike antigenic determinants including CD34+, VEGFR2, CD31+, CD133+, CD117+, P1H12+, cKit+, Sca1+ and CXCR4+ [26]. Yet at present, there are no surface markers that clearly distinguish early endothelial progenitors. The best approach currently is to define endothelial lineage functionally, in other words, by the ability of true EPCs to inosculate into a new or pre-existing vascular network [27]. Enhancement of EPCs is considered very promising therapeutic alternative for cardiovascular disease [28]. EPCs mobilization was successfully achieved by erythropoietin and other growth factors [29,30]. EPCs regeneration was found to increase by physical exercise in a nitric oxide-dependent way [31]. Statin therapy is an extensively studied pharmacological pathway known to increase EPCs mobilization [32-34]. Besides their lipid lowering and anti-inflammatory effect, statins work by direct stimulation of EPCs synthesis and release into the circulation, leading to an overall reduced aggression to the vascular wall and eventually passivate the vascular system [35].

\section{Mesenchymal Stem Cells (MSCs)}

Mesenchymal Stem Cells (MSCs) are multipotent non hematopoietic, fibroblast-like cells that can be isolated from various tissues, including Bone Marrow (BM), adipose tissue, placenta, and umbilical cord blood [36]. In addition to their differentiation capabilities into bone, fat ... etc., MSCs exert vascular therapeutic effects via secretion of paracrine factors that may have anti-inflammatory and immunomodulatory effects $[37,38]$. Of note, immune-modulation is a unique feature for MSCs, making their combination with other stem cells subtypes very appealing to enhance allogeneic injection for inducing repair [39-41].

\section{Clinical evidence of CLI in diabetes}

Clinically, CLI is somewhat regarded as a condition almost restricted to patients with diabetes mellitus, as it has been estimated that nearly $25 \%$ of patients with diabetes have evidence of CLI [42]. Recent reports showed that, diabetes can increase the risk of PAD by two- to four folds [42]. Moreover, the risk for PAD is aggravated by poor glycemic control in diabetic patients [43]. Since CLI is the last stage of arterial occlusive disease, atherosclerosis in association with hypertension, hypercholesterolemia, cigarette smoking and diabetes are the main risk factors. Less frequent causes of CLI are Buerger's disease, arteritis or thromboangiitis obliterans [44]. While, CLI does not occur solely in the diabetic patient population [45], data on CLI in non diabetic subjects are relatively scarce. Experimentally, the murine hind-limb ischemia model is the most commonly used as a preclinical model for PAD. In this model, the superficial femoral artery is ligated proximally and distally, and the segment in between the ligatures is excised. The common femoral artery is also ligated, to obstruct flow to the deep femoral artery. Typically, C57Bl6 mice are used over the age of 12 weeks, as younger animals recover so quickly and completely that angiogenic agents cannot be easily tested [27]. Majority of CLI preclinical data are generated using type 1 diabetic model induced by the toxin streptozotocin injection [46-48].

\section{Alteration of EPCs number and function in diabetes}

The number of circulating EPCs was found to be $44 \%$ lower in patients with diabetes [49] and in patients with PAD [50]. Diabetes can impair the function of EPCs as assessed by their ability to form colonies and to incorporate into pre-existing vascular networks ex vivo [51]. Type 2 diabetic patients were reported to have lower level of EPCs. Moreover, EPCs number 
extensively decreases in type 2 diabetic patients who develop peripheral vascular complications [52]. In support, Fadini GP, et al. [53] reported that EPCs could be novel biological marker of diabetic vasculopathy where diabetic patients with PAD displayed a significant $53 \%$ reduction in circulating EPCs versus patients without PAD. Type 1 diabetes is associated with reduced vascular repair as indicated by impaired wound healing and reduced collateral formation. These vascular complications in type1 diabetes were attributed to EPCs dysfunction [49].

\section{Clinical evidence of CLI in obesity}

Although diabetes is the most well-defined risk factor for the development of CLI, additional risk factors include the components of metabolic syndrome. Metabolic syndrome is a cluster of several cardiovascular risk factors, with insulin resistance as a major characteristic in addition to obesity, abdominal obesity, glucose intolerance, high blood pressure, and high cholesterol. Obesity is defined as a body weight that is greater than what would be considered a healthy weight for a given height. More than one third of adults in the United States are obese [54]. Obesity is more than just a cosmetic issue; the American Medical Association officially recognized obesity as a disease state in 2013 [42]. Obesity increases the risk of many health problems including but not limited to coronary heart disease, hypertension, stroke, type 2 diabetes, dyslipidemia, cancer, osteoarthritis, sleep apnea, gallstones, reproductive problems, and metabolic syndrome [55]. Metabolic syndrome is an accumulation of hypertriglyceridemia, hyperinsulinemia, abdominal adiposity, hypertension, and reduced HDL cholesterol, all of which occur due to its hallmark clinical features of central obesity and insulin resistance [56]. Insulin resistance increases the risk for a patient to develop ischemic cardiovascular diseases even in non-diabetic milieu [57]. The clinical manifestations of metabolic syndrome all contribute to the development of atherosclerotic blockages, so it is important to recognize the risk of CLI not only in the diabetic population, but also in the growing patient populations with obesity and/or metabolic syndrome.

\section{Experimental evidence of CLI in obesity}

Using hind limb ischemia model, Albadawi, et al. [58] has shown that diet-induced obesity in mice demonstrated defective functional recovery during the regenerative phase of limb ischemia-reperfusion injury. This finding could be of strong relevance to perfusion of lower extremity in patients with metabolic syndrome and insulin resistance. Our group has shown that, high fat diet-induced obesity can compromise vascular recovery in response to ischemic insult evident by impaired blood flow and significant reduction in vascular density compared to mice kept on normal diet. The mechanisms involve increasing oxidative and nitrative stress that impaired the signal of the Vascular Endothelial Growth Factor (VEGF) to its receptor (VEGFR2) in response to high fat diet [59]. Furthermore, Tsai, et al. [60] demonstrated that diet-induced obesity impaired recovery of the ischemic areas compared to normal diet. The mechanism was attributed to a decrease in number and function of circulating cells involved in endogenous repair.
Interestingly, when comparing the vascular recovery and neovascularization following hind limb ischemia in type 1 and type 2 diabetic mice, blood flow recovery was markedly reduced in both diabetic mice groups. Moreover, blood flow recovery was significantly less within type 2 diabetic mice compared to type 1 diabetic group [61]. These findings lend further support that other components including, hyperlipidemia and obesity, contribute to the observed impaired blood flow in type 2 diabetes compared to type- 1 .

\section{Impairment of EPCs number and function in obesity}

In addition to proven diabetes, patients with metabolic syndrome only were shown to have significantly lower number of EPCs as well as decreased function, demonstrated by decreased colony-forming capacity [62]. Furthermore, type 2 diabetes coupled with obesity seemed to induce intrinsic EC progenitor dysfunction [63]. Many studies reported the association of obesity with impaired EPCs number and function. Westerweel PE, et al. [64], reported that level of circulating EPCs was reduced by nearly $40 \%$ in obese men with metabolic syndrome, which was reversed by combination therapy of low-dose Statin with ezetimibe or high-dose Statin monotherapy. Obesity is associated with decreased numbers of circulating progenitor cells and increased carotid intima media thickness, which were reversed by weight loss [65]. MacEneaney OJ, et al. [66] showed that, number of circulating EPCs was lower in adult obese subjects compared to over-weight and normal weight adults. They also reported that, EPCs colony formation was significantly less in the obese and overweight compared with normal weight adults . Another study by Tobler K, et al. [67] reported decreased number and premature senescence of EPCs in obese volunteers which could function as early contributors to the development and progression of vascular dysfunction in obesity. In overweight adolescents, the number of CD34-negative EPCs, but not CD34-positive EPCs was reported to be higher which could indicate higher risk for future cardiovascular disease in obese teenagers [68]. About the underlying mechanism, Heida NM, et al. [42] reported that EPCs isolated from obese subjects showed impaired angiogenic capacity, which was associated with increased basal activation of the stress marker; p38 MAPK. Inhibition of p38 MAPK was able to restore angiogenic properties of EPCs. Persons who achieved significant weight reduction revealed normalization of p38 MAPK and improved EPCs function.

\section{Therapeutic utility of EPCs in CLI}

Teraa $M$, et al. [69] reported increased inflammation and reduced levels of BM and circulating EPCs in CLI patients. The patients experienced attenuated neovascularization, which was attributed to inflammation-induced BM exhaustion and a disturbed progenitor cell mobilization response. The therapeutic potential of EPCs was identified as early as 2003 in a study done by Kudo FA and colleagues, [70] where autologous transplantation of peripheral blood EPCs (CD34+) was reported to induce satisfactory clinical improvement in patients with CLI. Longer-term clinical benefits were also reported in a randomized, double-blinded, controlled study in which 28 patients with CLI 
received CD34+ cells intramuscularly. Patients showed decreased amputation rates and improved amputation-free survival [71].

\section{Therapeutic utility of BM-MNCs in CLI}

The first report of stem cell therapy for treatment of ischemic limbs was conducted by Tateishi-Yuyama, E et al. [17] using unselected MNCs from both the bone marrow and peripheral blood for the treatment of CLI . The safety and feasibility of BMMNCs in ischemic limb treatment was investigated thereafter in different studies [16,72]. As reported in many studies, intramuscular administration of BM-MNCs in ischemic limb improved clinical outcomes including improved ankle brachial index, pain-free walking distance/time, wound healing and limb salvage [73-76]. In support, recent studies confirmed the clinical improvement in patients with severe limb ischemia following intramuscular administration of BM-MNCs in terms of lower amputation rates and improved ankle-brachial index [77-79]. In contrast, a small randomized trial reported non-significant trends toward improved ankle brachial index, and wound healing in patients treated with BM-MNC [80].

\section{Therapeutic utility of MSCs in CLI}

The protective potential of MSC against hind limb ischemia was reported in many studies. Hypoxic preconditioning of MSCs was reported to improve their tissue regeneration potential in a murine model of hind limb ischemia, whereas, cells cultured under normoxic conditions exerted therapeutic potential but to lesser extent [81]. Preconditioning improved MSCs therapeutic potential owing to Hepatocyte Growth Factor (HGF)/c-Met signaling pathway as demonstrated by a subsequent study by the same group [82]. In support of this finding, Hoffmann, et al. [83] reported that transplantation of hypoxic MSCs into murine ischemic limbs resulted in increased vessel density . Optimal timing for MSCs injection is crucial as well where administration of MSCs or conditioned media immediately after induction of hind-limb ischemia did not improve revascularization but did do so when administered one day later as reported by Kinnaird $\mathrm{T}$, et al. [84].

In a mouse model of CLI, placental-derived Adherent Stromal Cells (ASCs) were found to rescue limb function. These cells share the adherence and marker expression of BM-derived MSCs but lack their differentiation potential [85]. In addition, priming human MSCs chemically to enhance the angiogenic potential by increasing the levels of VEGF and hepatocyte growth factor without genetic modification of MSC potentiated therapeutic angiogenesis and cell survival in the same mouse model [86].

Clinically, human umbilical cord blood-derived MSCs relieved ischemic rest pain in patients with Buerger's disease and in an animal model of hind limb ischemia as well [87]. Intravenous administration of autologous BM-derived MSCs was shown to improve revascularization in a patient suffering from acute gangrene of upper and lower limbs secondary to systemic sclerosis [88]. Couple of studies showed that intramuscular injection of a combination of MSCs and BM-MNC improved walking time, ankle brachial pressure and quality of life in patients with diabetes mellitus and moderate to severe PAD [89,90]. Meanwhile, Lu D, et al. [91]reported that BM-MSCs could be better tolerated and more effective than BM-MNCs in increasing lower limb perfusion and promoting foot ulcer healing in their study done on 41 CLI patients with diabetes mellitus .

\section{Future and challenges in cell therapy}

So far, the development of stem cell therapies to treat PAD has proven difficult for multiple reasons including the complex nature and multiplicity of cell types that coordinate revascularization as well as limitation of the regenerative potential of transplanted human bone marrow derived cells [92]. Challenges facing stem cell-based vascular recovery start with isolation of a particular subtype. Isolation of MSCs or EPCs is relatively easy as they can be collected from bone marrow or peripheral blood. Meanwhile, organ-originated stem cells are difficult to collect because of their unique location and limited number [93]. Ex vivo expansion and purification of specific subpopulation is another challenge, with administration of exogenous cytokines as well as flow cytometry being applicable [94]. Moreover, cells can be dysfunctional with impaired regenerative ability owing to genetics, disease, injury or aging. Integration among native body cells and immunological rejection are also debatable. Additional efforts to improve selection of BM-MNCs with higher regenerative ability are in progress. For instance, human BM-MNCs was isolated and enriched for high Aldehyde Dehydrogenase (ALDH), which is an oxidizing enzyme highly expressed in both embryonic and adult stem cells. The regenerative capacity of human ALDH cells was assessed by intravenous transplantation into immune-deficient mice with limb ischemia. Compared with recipients injected with unpurified nucleated cells containing the equivalent of 2 - to 4-fold more ALDH cells, mice transplanted with purified ALDH cells showed augmented recovery of perfusion and increased blood vessel density in ischemic limbs [95]. The majority of studies on cell therapy for CLI have used whole MNC fractions and at this moment it is unclear whether administration of more selected cell populations or ex-vivo culture toward an endothelial phenotype would be more effective [96].

In Summary, there is clinical and experimental evidence that obesity and insulin resistance without incidence of frank diabetes can be associated with impaired perfusion to lower extremities that can progress into critical limb ischemia. Over the past 15 years, there is general agreement that stem cells are useful for vascular diseases. Yet, cell therapy is faced with multiple challenges starting with identification and isolation of a particular stem cell subtype through targeted differentiation. Researches have to overcome these challenges before stem cell therapy can be a successful reality for vascular diseases.

\section{References}

1. Norgren L, Hiatt WR, Dormandy JA, Nehler MR, Harris KA, Fowkes FG, et al. Inter-society consensus for the management of peripheral arterial disease. International angiology : a Journal of the International Union of Angiology. 2007;26(2):81-157.

2. Liew A, O’Brien T. Therapeutic potential for mesenchymal stem cell transplantation in critical limb ischemia. Stem Cell Res Ther. 2012;3(4):28. doi: 10.1186/scrt119. 
3. White JV, Rutherford RB, Ryjewski C. Chronic subcritical limb ischemia: a poorly recognized stage of critical limb ischemia. Semin Vasc Surg. 2007;20(1):62-7.

4. Norgren L, Hiatt WR, Dormandy JA, Nehler MR, Harris KA, Fowkes FG. Inter-Society Consensus for the Management of Peripheral Arterial Disease (TASC II). J Vasc Surg. 2007;45 Suppl S:S5-67.

5. Hadi HA, Carr CS, Al Suwaidi J. Endothelial dysfunction: cardiovascular risk factors, therapy, and outcome. Vasc Health Risk Manag. 2005;1(3):183-98.

6. Cooke JP, Dzau VJ. Nitric oxide synthase: role in the genesis of vascular disease. Annu Rev Med. 1997;48:489-509.

7. Hirsch AT, Haskal ZJ, Hertzer NR, Bakal CW, Creager MA, Halperin JL, et al. ACC/AHA 2005 Practice Guidelines for the management of patients with peripheral arterial disease (lower extremity, renal, mesenteric, and abdominal aortic): a collaborative report from the American Association for Vascular Surgery/Society for Vascular Surgery, Society for Cardiovascular Angiography and Interventions, Society for Vascular Medicine and Biology, Society of Interventional Radiology, and the ACC/AHA Task Force on Practice Guidelines (Writing Committee to Develop Guidelines for the Management of Patients With Peripheral Arterial Disease): endorsed by the American Association of Cardiovascular and Pulmonary Rehabilitation; National Heart, Lung, and Blood Institute; Society for Vascular Nursing; TransAtlantic Inter-Society Consensus; and Vascular Disease Foundation. Circulation. 2006;113(11):e463-654.

8. Ouriel K. Peripheral arterial disease. Lancet. 2001;358(9289):125764.

9. Folkman J. Tumor angiogenesis: therapeutic implications. N Engl J Med. 1971;18;285(21):1182-6

10. Moeller BJ, Cao Y, Vujaskovic Z, Li CY, Haroon ZA, Dewhirst MW. The relationship between hypoxia and angiogenesis. Seminars in radiation oncology. 2004;14(3):215-21.

11. Buschmann I, Schaper W. The pathophysiology of the collateral circulation (arteriogenesis). J Pathol. 2000;190(3):338-42.

12. Devanesan AJ, Laughlan KA, Girn HR, Homer-Vanniasinkam S Endothelial progenitor cells as a therapeutic option in peripheral arterial disease. Eur J Vasc Endovasc Surg. 2009;38(4):475-81. doi: 10.1016/j.ejvs.2009.05.019.

13. Hickman P, Harrison DK, Hill A, McLaren M, Tamei H, McCollum PT, et al. Exercise in patients with intermittent claudication results in the generation of oxygen derived free radicals and endothelial damage. Adv Exp Med Biol. 1994;361:565-70.

14. Davis C, Fischer J, Ley K, Sarembock IJ. The role of inflammation in vascular injury and repair. J Thromb Haemost. 2003;1(8):1699-709.

15. Moreno PR, Sanz J, Fuster V. Promoting mechanisms of vascular health: circulating progenitor cells, angiogenesis, and reverse cholesterol transport. J Am Coll Cardiol. 2009 Jun 23;53(25):2315-23. doi: 10.1016/j.jacc.2009.02.057.

16. Gupta NK, Armstrong EJ, Parikh SA. The current state of stem cell therapy for peripheral artery disease. Curr Cardiol Rep. 2014;16(2):447. doi: 10.1007/s11886-013-0447-2.

17. Tateishi-Yuyama E, Matsubara H, Murohara T, Ikeda U, Shintani $\mathrm{S}$, Masaki $\mathrm{H}$, et al. Therapeutic angiogenesis for patients with limb ischaemia by autologous transplantation of bone-marrow cells: a pilot study and a randomised controlled trial. Lancet. 2002;360(9331):42735 .

Citation: Elshaer SL, Lorys RE, El-Remessy AB (2016) Cell Therapy and Critical Limb Ischemia: Evidence and Window of Opportunity in Obesity. Obes Control Ther 3(1): 1-8. DOI: http://dx.doi.org/10.15226/2374-8354/2/2/00121
18. Lu SJ, Ivanova Y, Feng Q, Luo C, Lanza R. Hemangioblasts from human embryonic stem cells generate multilayered blood vessels with functional smooth muscle cells. Regen Med. 2009;4(1):37-47. doi: 10.2217/17460751.4.1.37.

19. Dimmeler S, Burchfield J, Zeiher AM. Cell-based therapy of myocardial infarction. Arterioscler Thromb Vasc Biol. 2008;28(2):208-16.

20.Young HE, Duplaa C, Katz R, Thompson T, Hawkins KC, Boev AN, et al. Adult-derived stem cells and their potential for use in tissue repair and molecular medicine. J Cell Mol Med. 2005;9(3):753-69.

21. Leeper NJ, Hunter AL, Cooke JP. Stem cell therapy for vascular regeneration: adult, embryonic, and induced pluripotent stem cells. Circulation. 2010 3;122(5):517-26. doi: 10.1161/ CIRCULATIONAHA.109.881441.

22. Barber CL, Iruela-Arispe ML. The ever-elusive endothelial progenitor cell: identities, functions and clinical implications. Pediatr Res. 2006; 59(4 Pt 2):26R-32R.

23. Kamihata H, Matsubara H, Nishiue T, Fujiyama S, Tsutsumi Y, Ozono $\mathrm{R}$, et al. Implantation of bone marrow mononuclear cells into ischemic myocardium enhances collateral perfusion and regional function via side supply of angioblasts, angiogenic ligands, and cytokines. Circulation. 2001;104(9):1046-52.

24.Yoder MC. Human endothelial progenitor cells. Cold Spring Harb Perspect Med. 2012;2(7):a006692. doi: 10.1101/cshperspect. a006692.

25. Asahara T, Murohara T, Sullivan A, Silver M, van der Zee R, Li T, et al. Isolation of putative progenitor endothelial cells for angiogenesis. Science. 1997;275(5302):964-7.

26. Zampetaki A, Kirton JP, Xu Q. Cardiovascular research. 2008;78(3):41321. Cardiovasc Res. 2008 1;78(3):413-21. doi: 10.1093/cvr/cvn081.

27. Cooke JP, Losordo DW. Modulating the vascular response to limb ischemia: angiogenic and cell therapies. Circ Res. 2015;116(9):156178. doi: 10.1161/CIRCRESAHA.115.303565.

28. Dong C, Goldschmidt-Clermont PJ. Endothelial progenitor cells: a promising therapeutic alternative for cardiovascular disease. J Interv Cardiol. 2007;20(2):93-9.

29. Urao N, Okigaki M, Yamada H, Aadachi Y, Matsuno K, Matsui A, et al. Erythropoietin-mobilized endothelial progenitors enhance reendothelialization via Akt-endothelial nitric oxide synthase activation and prevent neointimal hyperplasia. Circ Res. 2006;98(11):1405-13.

30. Yoshioka T, Takahashi M, Shiba Y, Suzuki C, Morimoto H, Izawa A, et al. Granulocyte colony-stimulating factor (G-CSF) accelerates reendothelialization and reduces neointimal formation after vascular injury in mice. Cardiovasc Res. 2006;70(1):61-9

31. Linke A, Erbs S, Hambrecht R. Effects of exercise training upon endothelial function in patients with cardiovascular disease. Front Biosci. 2008;13:424-32.

32. Deschaseaux F, Selmani Z, Falcoz PE, Mersin N, Meneveau N, Penfornis A, et al. Two types of circulating endothelial progenitor cells in patients receiving long term therapy by HMG-CoA reductase inhibitors. Eur J Pharmacol. 2007;562(1-2):111-8.

33. Kusuyama T, Omura T, Nishiya D, Enomoto S, Matsumoto R, Murata $\mathrm{T}$, et al. The effects of HMG-CoA reductase inhibitor on vascular progenitor cells. J Pharmacol Sci. 2006;101(4):344-9.

34. Walter DH, Rittig K, Bahlmann FH, Kirchmair R, Silver M, Murayama $\mathrm{T}$, et al. Statin therapy accelerates reendothelialization: a novel effect 
involving mobilization and incorporation of bone marrow-derived endothelial progenitor cells. Circulation. 2002;105(25):3017-24.

35. Hristov M, Fach C, Becker C, Heussen N, Liehn EA, Blindt R, et al. Reduced numbers of circulating endothelial progenitor cells in patients with coronary artery disease associated with long-term statin treatment. Atherosclerosis. 2007;192(2):413-20.

36. Barry FP, Murphy JM. Mesenchymal stem cells: clinical applications and biological characterization. Int J Biochem Cell Biol. 2004 ;36(4):568-84.

37. Ishikane S, Ohnishi S, Yamahara K, Sada M, Harada K, Mishima K, et al. Allogeneic injection of fetal membrane-derived mesenchymal stem cells induces therapeutic angiogenesis in a rat model of hind limb ischemia. Stem Cells. 2008 ;26(10):2625-33. doi: 10.1634/ stemcells.2008-0236.

38. Liao W, Zhong J, Yu J, Xie J, Liu Y, Du L, et al. Therapeutic benefit of human umbilical cord derived mesenchymal stromal cells in intracerebral hemorrhage rat: implications of anti-inflammation and angiogenesis. Cell Physiol Biochem. 2009;24(3-4):307-16. doi: $10.1159 / 000233255$

39. Lee MW, Ryu S, Kim DS, Sung KW, Koo HH, Yoo KH. Strategies to improve the immunosuppressive properties of human mesenchymal stem cells. Stem cell research \& therapy. 2015;6:179.

40. Shi Y, Hu G, Su J, Li W, Chen Q, Shou P, et al. Mesenchymal stem cells: a new strategy for immunosuppression and tissue repair. Cell Res. 2010;20(5):510-8. doi: 10.1038/cr.2010.44.

41. Xiong YY, Fan Q, Huang F, Zhang Y, Wang Y, Chen XY, et al. Mesenchymal stem cells versus mesenchymal stem cells combined with cord blood for engraftment failure after autologous hematopoietic stem cell transplantation: a pilot prospective, open-label, randomized trial. Biol Blood Marrow Transplant. 2014;20(2):236-42. doi: 10.1016/j. bbmt.2013.11.002.

42. Heida NM, Muller JP, Cheng IF, Leifheit-Nestler M, Faustin V, Riggert $\mathrm{J}$, et al. Effects of obesity and weight loss on the functional properties of early outgrowth endothelial progenitor cells. J Am Coll Cardiol. 2010;55(4):357-67. doi: 10.1016/j.jacc.2009.09.031.

43. Selvin E, Wattanakit K, Steffes MW, Coresh J, Sharrett AR. HbA1c and peripheral arterial disease in diabetes: the Atherosclerosis Risk in Communities study. Diabetes Care. 2006;29(4):877-82.

44. Santilli JD, Santilli SM. Chronic critical limb ischemia: diagnosis, treatment and prognosis. American family physician. 1999;59(7):1899-908.

45. Jude EB, Oyibo SO, Chalmers N, Boulton AJ. Peripheral arterial disease in diabetic and nondiabetic patients: a comparison of severity and outcome. Diabetes care. 2001;24(8):1433-7.

46. Caporali A, Meloni M, Nailor A, Mitic T, Shantikumar S, Riu F, et al. p75(NTR)-dependent activation of NF- $\kappa$ B regulates microRNA-503 transcription and pericyte-endothelial crosstalk in diabetes after limb ischaemia. Nat Commun. 2015;6:8024. doi: 10.1038/ncomms9024.

47. Caporali A, Pani E, Horrevoets AJ, Kraenkel N, Oikawa A, Sala-Newby GB, et al. Neurotrophin p75 receptor (p75NTR) promotes endothelial cell apoptosis and inhibits angiogenesis: implications for diabetesinduced impaired neovascularization in ischemic limb muscles. Circ Res. 2008 18;103(2):e15-26. doi: 10.1161/CIRCRESAHA.108.177386.

48. Salis MB, Graiani G, Desortes E, Caldwell RB, Madeddu P, Emanueli C. Nerve growth factor supplementation reverses the impairment, induced by Type 1 diabetes, of hindlimb post-ischaemic recovery in mice. Diabetologia. 2004;47(6):1055-63.
49. Loomans CJ, de Koning EJ, Staal FJ, Rookmaaker MB, Verseyden C, de Boer HC, et al. Endothelial progenitor cell dysfunction: a novel concept in the pathogenesis of vascular complications of type 1 diabetes. Diabetes. 2004;53(1):195-9

50. Morishita T, Uzui H, Nakano A, Mitsuke Y, Geshi T, Ueda T, et al. Number of endothelial progenitor cells in peripheral artery disease as a marker of severity and association with pentraxin-3, malondialdehydemodified low-density lipoprotein and membrane type- 1 matrix metalloproteinase. J Atheroscler Thromb. 2012;19(2):149-58.

51.Jung C, Rafnsson A, Shemyakin A, Bohm F, Pernow J. Different subpopulations of endothelial progenitor cells and circulating apoptotic progenitor cells in patients with vascular disease and diabetes. Int J Cardiol. 2010 3;143(3):368-72. doi: 10.1016/j. ijcard.2009.03.075.

52. Fadini GP, Miorin M, Facco M, Bonamico S, Baesso I, Grego F, et al. Circulating endothelial progenitor cells are reduced in peripheral vascular complications of type 2 diabetes mellitus. J Am Coll Cardiol. 2005;45(9):1449-57.

53. Fadini GP, Sartore S, Albiero M, Baesso I, Murphy E, Menegolo M, et al. Number and function of endothelial progenitor cells as a marker of severity for diabetic vasculopathy. Arterioscler Thromb Vasc Biol. 2006;26(9):2140-6.

54. Ogden CL, Carroll MD, Kit BK, Flegal KM. Prevalence of childhood and adult obesity in the United States, 2011-2012. JAMA. 2014;311(8):80614. doi: 10.1001/jama.2014.732.

55. What Are the Health Risks of Overweight and Obesity? 2012.

56. O'Neill S, O'Driscoll L. Metabolic syndrome: a closer look at the growing epidemic and its associated pathologies. Obes Rev. 2015;16(1):1-12. doi: 10.1111/obr.12229.

57. Mottillo S, Filion KB, Genest J, Joseph L, Pilote L, Poirier P, et al. The metabolic syndrome and cardiovascular risk a systematic review and meta-analysis. J Am Coll Cardiol. 2010;56(14):1113-32. doi: 10.1016/j.jacc.2010.05.034.

58. Albadawi H, Oklu R, Cormier NR, O'Keefe RM, Heaton JT, Kobler JB, et al. Hind limb ischemia-reperfusion injury in diet-induced obese mice. J Surg Res. 2014;190(2):683-91. doi: 10.1016/j.jss.2014.01.020.

59. Eldahshan W, Elshaer S, Mohamed I, Coucha M, Bartasis M, Hoda M, et al. Deletion of TXNIP improves high-fat diet-impaired vascular recovery in hind limb ischemic model. American diabetes association, 75th scientific sessions. 2015.

60.Tsai TH, Chai HT, Sun CK, Yen CH, Leu S, Chen YL, et al. Obesity suppresses circulating level and function of endothelial progenitor cells and heart function. J Transl Med. 2012;10:137. doi: 10.1186/14795876-10-137.

61. Yan J, Tie G, Park B, Yan Y, Nowicki PT, Messina LM. Recovery from hind limb ischemia is less effective in type 2 than in type 1 diabetic mice: roles of endothelial nitric oxide synthase and endothelial progenitor cells. J Vasc Surg. 2009;50(6):1412-22. doi: 10.1016/j. jvs.2009.08.007.

62. Jialal I, Devaraj S, Singh U, Huet BA. Decreased number and impaired functionality of endothelial progenitor cells in subjects with metabolic syndrome: implications for increased cardiovascular risk. Atherosclerosis. 2010;211(1):297-302. doi: 10.1016/j. atherosclerosis.2010.01.036.

63. Awad O, Jiao C, Ma N, Dunnwald M, Schatteman GC. Obese diabetic mouse environment differentially affects primitive and monocytic endothelial cell progenitors. Stem Cells. 2005;23(4):575-83. 
64. Westerweel PE, Visseren FL, Hajer GR, Olijhoek JK, Hoefer IE, de Bree P, et al. Endothelial progenitor cell levels in obese men with the metabolic syndrome and the effect of simvastatin monotherapy vs. simvastatin/ ezetimibe combination therapy. Eur Heart J. 2008;29(22):2808-17. doi: 10.1093/eurheartj/ehn431.

65. Muller-Ehmsen J, Braun D, Schneider T, Pfister R, Worm N, Wielckens $\mathrm{K}$, et al. Decreased number of circulating progenitor cells in obesity: beneficial effects of weight reduction. Eur Heart J. 2008;29(12):15608. doi: 10.1093/eurheartj/ehn213.

66. MacEneaney OJ, Kushner EJ, Van Guilder GP, Greiner JJ, Stauffer BL, DeSouza CA. Endothelial progenitor cell number and colonyforming capacity in overweight and obese adults. Int J Obes (Lond). 2009;33(2):219-225. doi: 10.1038/ijo.2008.262.

67. Tobler K, Freudenthaler A, Baumgartner-Parzer SM, Wolzt M, Ludvik B, Nansalmaa E, et al. Reduction of both number and proliferative activity of human endothelial progenitor cells in obesity. Int J Obes (Lond). 2010;34(4):687-700. doi: 10.1038/ijo.2009.280.

68. Jung C, Fischer N, Fritzenwanger M, Thude H, Ferrari M, Fabris M, et al. Endothelial progenitor cells in adolescents: impact of overweight, age, smoking, sport and cytokines in younger age. Clin Res Cardiol. 2009;98(3):179-188. doi: 10.1007/s00392-008-0739-5.

69. Teraa M, Sprengers RW, Westerweel PE, Gremmels H, Goumans MJ, Teerlink T, et al. Bone marrow alterations and lower endothelial progenitor cell numbers in critical limb ischemia patients. PLoS One. 2013;8(1):e55592. doi: 10.1371/journal.pone.0055592.

70. Kudo FA, Nishibe T, Nishibe M, Yasuda K. Autologous transplantation of peripheral blood endothelial progenitor cells (CD34+) for therapeutic angiogenesis in patients with critical limb ischemia. Int Angiol. 2003;22(4):344-8.

71. Losordo DW, Kibbe MR, Mendelsohn F, Marston W, Driver VR Sharafuddin M, et al. A randomized, controlled pilot study of autologous CD34+ cell therapy for critical limb ischemia. Circ Cardiovasc Interv. 2012;5(6):821-830. doi: 10.1161/CIRCINTERVENTIONS.112.968321.

72. Raval Z, Losordo DW. Cell therapy of peripheral arterial disease: from experimental findings to clinical trials. Circ Res. 2013;112(9):12881302. doi: 10.1161/CIRCRESAHA. 113.300565.

73. Duong Van Huyen JP, Smadja DM, Bruneval P, Gaussem P, Dal-Cortivo L, Julia $\mathrm{P}$, et al. Bone marrow-derived mononuclear cell therapy induces distal angiogenesis after local injection in critical leg ischemia. Mod Pathol. 2008;21(7):837-46. doi: 10.1038/modpathol.2008.48.

74. Higashi Y, Kimura M, Hara K, Noma K, Jitsuiki D, Nakagawa K, et al. Autologous bone-marrow mononuclear cell implantation improves endothelium-dependent vasodilation in patients with limb ischemia. Circulation. 2004;109(10):1215-8.

75. Motukuru V, Suresh KR, Vivekanand V, Raj S, Girija KR. Therapeutic angiogenesis in Buerger's disease (thromboangiitis obliterans) patients with critical limb ischemia by autologous transplantation of bone marrow mononuclear cells. J Vasc Surg. 2008;48(6 Suppl):53S60S; discussion 60S. doi: 10.1016/j.jvs.2008.09.005.

76. Saito Y, Sasaki K, Katsuda Y, Murohara T, Takeshita Y, Okazaki T, et al. Effect of autologous bone-marrow cell transplantation on ischemic ulcer in patients with Buerger's disease. Circ J. 2007;71(8):1187-92.

77. Benoit E, O’Donnell TF, Jr., Iafrati MD, Asher E, Bandyk DF, Hallett JW, et al. The role of amputation as an outcome measure in cellular therapy for critical limb ischemia: implications for clinical trial design. J Transl Med. 2011;9:165. doi: 10.1186/1479-5876-9-165.

78. Iafrati MD, Hallett JW, Geils G, Pearl G, Lumsden A, Peden E, et al.
Early results and lessons learned from a multicenter, randomized, double-blind trial of bone marrow aspirate concentrate in critical limb ischemia. J Vasc Surg. 2011;54(6):1650-8. doi: 10.1016/j. jvs.2011.06.118.

79. Prochazka V, Gumulec J, Jaluvka F, Salounova D, Jonszta T, Czerny D, et al. Cell therapy, a new standard in management of chronic critical limb ischemia and foot ulcer. Cell Transplant. 2010;19(11):1413-24. doi: 10.3727/096368910X514170.

80. Kirana S, Stratmann B, Prante C, Prohaska W, Koerperich H, Lammers $\mathrm{D}$, et al. Autologous stem cell therapy in the treatment of limb ischaemia induced chronic tissue ulcers of diabetic foot patients. Int J Clin Pract. 2012;66(4):384-93. doi: 10.1111/j.1742-1241.2011.02886.x.

81. Rosova I, Dao M, Capoccia B, Link D, Nolta JA. Hypoxic preconditioning results in increased motility and improved therapeutic potential of human mesenchymal stem cells. Stem Cells. 2008;26(8):2173-82. doi: 10.1634/stemcells.2007-1104.

82. Rosova I, Link D, Nolta JA. shRNA-mediated decreases in c-Met levels affect the differentiation potential of human mesenchymal stem cells and reduce their capacity for tissue repair. Tissue Eng Part A. 2010;16(8):2627-39. doi: 10.1089/ten.TEA.2009.0363.

83. Hoffmann J, Glassford AJ, Doyle TC, Robbins RC, Schrepfer S, Pelletier MP. Angiogenic effects despite limited cell survival of bone marrowderived mesenchymal stem cells under ischemia. Thorac Cardiovasc Surg. 2010;58(3):136-42. doi: 10.1055/s-0029-1240758.

84. Kinnaird T, Stabile E, Burnett MS, Shou M, Lee CW, Barr S, et al. Local delivery of marrow-derived stromal cells augments collateral perfusion through paracrine mechanisms. Circulation. 2004;109(12):1543-9.

85. Prather WR, Toren A, Meiron M, Ofir R, Tschope C, Horwitz EM. The role of placental-derived adherent stromal cell (PLX-PAD) in the treatment of critical limb ischemia. Cytotherapy. 2009;11(4):427-34. doi: $10.1080 / 14653240902849762$.

86. Lee EJ, Park HW, Jeon HJ, Kim HS, Chang MS. Potentiated therapeutic angiogenesis by primed human mesenchymal stem cells in a mouse model of hindlimb ischemia. Regen Med. 2013;8(3):283-93. doi: 10.2217/rme.13.17.

87. Kim SW, Han H, Chae GT, Lee SH, Bo S, Yoon JH, et al. Successful stem cell therapy using umbilical cord blood-derived multipotent stem cells for Buerger's disease and ischemic limb disease animal model. Stem Cells. 2006;24(6):1620-6.

88. Guiducci S, Porta F, Saccardi R, Guidi S, Ibba-Manneschi L, Manetti M, et al. Autologous mesenchymal stem cells foster revascularization of ischemic limbs in systemic sclerosis: a case report. Ann Intern Med. 2010;153(10):650-4. doi: 10.7326/0003-4819-153-10-20101116000007.

89. Lasala GP, Silva JA, Gardner PA, Minguell JJ. Combination stem cell therapy for the treatment of severe limb ischemia: safety and efficacy analysis. Angiology. 2010;61(6):551-6. doi: 10.1177/0003319710364213.

90. Lasala GP, Silva JA, Minguell JJ. Therapeutic angiogenesis in patients with severe limb ischemia by transplantation of a combination stem cell product. J Thorac Cardiovasc Surg. 2012;144(2):377-382. doi: 10.1016/j.jtcvs.2011.08.053.

91.Lu D, Chen B, Liang Z, Deng W, Jiang Y, Li S, et al. Comparison of bone marrow mesenchymal stem cells with bone marrow-derived mononuclear cells for treatment of diabetic critical limb ischemia and 
foot ulcer: a double-blind, randomized, controlled trial. Diabetes Res Clin Pract. 2011;92(1):26-36. doi: 10.1016/j.diabres.2010.12.010.

92. Moreb JS. Aldehyde dehydrogenase as a marker for stem cells. Curr Stem Cell Res Ther. 2008;3(4):237-246.

93. Sun Q, Zhang Z, Sun Z. The potential and challenges of using stem cells for cardiovascular repair and regeneration. Genes \& Diseases. 2014;1(1):113-9.
94.Lev S, Kehat I, Gepstein L. Differentiation pathways in human embryonic stem cell-derived cardiomyocytes. Ann N Y Acad Sci. 2005;1047:50-65.

95. Capoccia BJ, Robson DL, Levac KD, Maxwell DJ, Hohm SA, Neelamkavil MJ, et al. Revascularization of ischemic limbs after transplantation of human bone marrow cells with high aldehyde dehydrogenase 